\title{
EDITORIAL
}

\section{Embracing the International Year of Light (2015)}

Light: Science \& Applications (2015) 4, e236; doi:10.1038/lsa.2015.9; published online 2 January 2015

$\mathrm{T}$ he United Nations Educational, Scientific and Cultural Organization (UNESCO) names 2015 the International Year of Light and Light-based Technologies, and will hold a series of commemorative activities. Not only working as a researcher in optics and an administrator on optics, but also serving as the editorin-chief for a journal named after 'light', I am very pleased with excitement on the progress of optics in the past, when welcoming the new era in the future. On behalf of the editorial board of Light: Science \& Applications, and also as a representative from tens of thousands of researchers in optics from China, I express my sincere and warm congratulations to the International Year of Light.

People's understanding on light has never been so deep and widespread like today. With respect to optics, more and more people in the world are working on research and development, including nature of light, light-matter interaction, energy conversion between light and other forms, optical information carrier using many unique advantages of light, and powerful tools based on light for the transformation and adaptation to the nature. We believe that the International Year of Light will play a catalytic role in all these activities, and as a result, will promote the development and progress of mankind.

Ever since 1950s, the optical business in China has been well conceived and rapidly developed. As the most populous country, China has the most people in the world, studying optical science and engineering, conducting research and development in optics, carrying out industries relevant to optics and applying the latest new optoelectronic products. Chinese people are trying to understand, investigate and exploit optics, and use light to create a bright future for not only their own, but people in the world. Since China is the largest developing country in the world, we know the existing gap between China and developed countries, and we are particularly willing to learn from colleagues from around the world. We sincerely hope that the International
Year of Light can provide more opportunities for all exchanges in optics between China and the world.

I wish a complete success of all activities at the International Year of Light, and I also wish a further rapid progress of the cause of global optics, including all research \& development, and industrialization \& commercialization relevant to Light: Science \& Applications.

Jianlin Cao, $\mathrm{PhD}$ Professor in Film Optics Editor-in-Chief,

Light: Science \& Applications

Vice Minister of Science and Technology of the People's Republic of China State Key Laboratory of Applied Optics, CIOMP, No. 3888, Dongnanhu Road, Changchun, China

(c) This work is licensed under a Creative Commons Attribution-NonCommercial-NoDerivative Works 3.0 Unported License. To view a copy of this license, visit http:// creativecommons.org/licenses/by-nc-nd/3.0

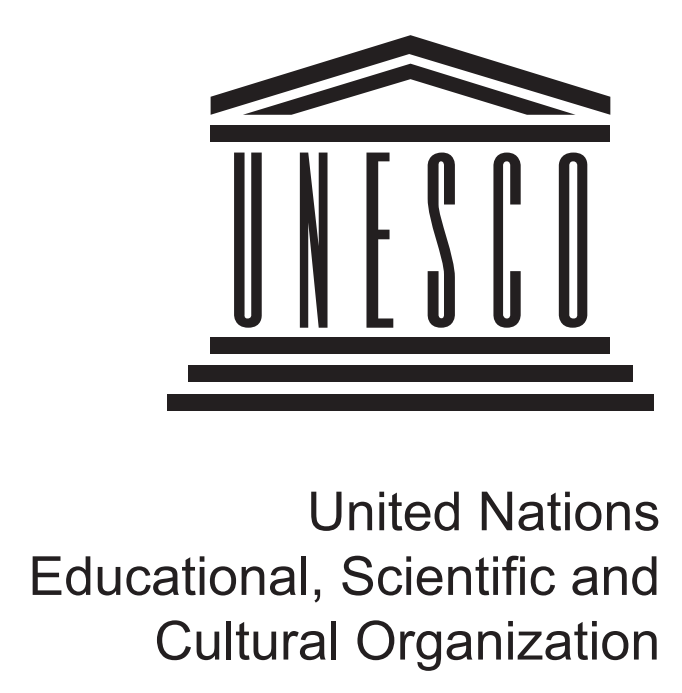

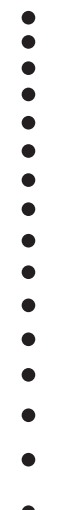

$\bullet$
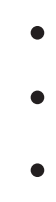

\section{In partnership with}

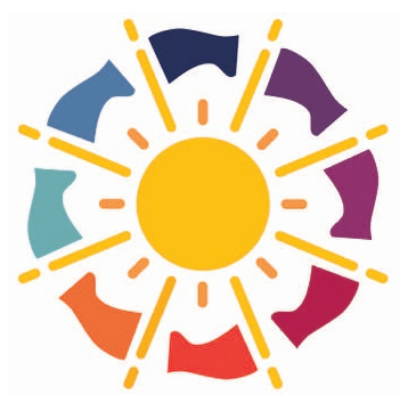

International Year of Light 2015 